\title{
Synthesis and Characterisation of New Monomethoxypoly(Ethylene Glycol) (mPEG) Carbonate Ester Surfactants
}

\author{
Joseph Arukwe, ${ }^{*}$ Balin Balinov, Gunnar Hagelin, Harald Dugstad and Terje Thomassen
}

NYCOMED Imaging, Department of Chemistry, Exploratory Research, PO Box 420, Torshov, N0401 Oslo, Norway

\begin{abstract}
Arukwe, J., Balinov, B., Hagelin, G., Dugstad, H. and Thomassen, T., 1999. Synthesis and Characterisation of New Monomethoxypoly(Ethylene Glycol) (mPEG) Carbonate Ester Surfactants. Acta Chem. Scand. 53: 594 601. (C) Acta Chemica Scandinavica 1999.

New $\mathbf{A} \mathbf{B}$ and $\mathbf{A}-\mathbf{B}-\mathbf{A}$ carbonate-esters, where $\mathbf{A}$ represents the hydrophilic part and $\mathbf{B}$ the lipophilic part, comprising monomethoxypoly(ethylene glycol) (mPEG) and a long chain carboxylic acid, have been synthesised. The synthetic approach to these compounds involved the alkylative esterification of aliphatic carboxylic acid as the key step. For the A B type compounds, the palmitic acid salt reacted chemoselectively with ambident $\boldsymbol{x}$-chloroalkylcarbonates $\mathbf{8}$ in DMF provided cesium was the counter-ion. With methyl substitution on the alkyl halide the mode of reaction was slightly altered, leading to unravelling of the alkylating agent structure via a presumed interaction with DMF. The decomposition fragments were detected in HPLC and in NMR designed experiments. For the $\mathbf{A}-\mathbf{B}-\mathbf{A}$ analogue, the tetrabutylammonium salt of docosanedioic acid was first alkylated with an ethylthio derivative of chloromethyl chloroformate and then converted into the carboyl chloride that was used effectively to acylate mPEG alcohol. These new compounds have been studied to establish their properties as surfactants. Enzymatic hydrolysis studies have shown enhanced degradation of the carbonate ester function in comparison with ordinary esters.
\end{abstract}

Surfactants are useful additives in many industrial and pharmaceutical applications. ${ }^{1}$ The chemical structures of most surfactants are amphiphilic, i.e. they contain both a hydrophilic and a hydrophobic part. Since most pharmaceutical applications involve aqueous solutions, non-ionic surfactants consisting of poly(ethylene glycol) (PEG) as the hydrophilic component are particularly attractive. ${ }^{2}$ PEG presents outstanding physico-chemical and biological properties, such as solubility in water and organic solvents, ease of chemical modification, ${ }^{3}$ lack of toxicity and absence of antigenicity and immunogenicity. ${ }^{4}$ Commercially available surfactants that have PEG block lengths include ethers of the type $\mathrm{R}\left(\mathrm{OCH}_{2} \mathrm{CH}_{2}\right)_{n} \mathrm{OH}$ and esters of the type $\mathrm{RCO}\left(\mathrm{OCH}_{2} \mathrm{CH}_{2}\right)_{n} \mathrm{OH}$, where $\mathrm{R}$ represents a long-chain aliphatic group, and are marketed under the trade names Brij and Myrj, respectively. ${ }^{5}$ By appropriately balancing the length of the hydrophobic fatty moiety and the degree of polymerisation of the hydrophilic poly(ethylene glycol) segment, a wide variety of surfactant properties may be achieved and have been used in many cosmetic, pharmaceutical and industrial applications, for example as emulsifiers, wetting agents, solubilisers, defoamers,

* To whom correspondence should be addressed. conditioning agents, lubricants and detergents. ${ }^{1}$ Considering their widespread use it is desirable that PEG-based surfactants should exhibit a significant degree of biodegradability in order to minimise the risk of environmental accumulation. Whilst the ester linkage between PEG and fatty acid moieties will ultimately be hydrolytically cleaved, surfactants exhibiting a higher rate of hydrolysis may possess a number of significant advantages. It is with this consideration in mind that we undertook to design, synthesise and evaluate the carbonate ester surfactants $\mathbf{1}$ and $\mathbf{2}$ shown in Fig. 1. Both structures will be designated as $\mathbf{A}-\mathbf{B}$ - and $\mathbf{A}-\mathbf{B}-\mathbf{A}$-type surfactants. The degree of polymerisation of $\mathrm{mPEG}$ was<smiles>[R2]C(=O)OC([R])OC(=O)OCCOC(C)C</smiles><smiles>[R]C(OC(=O)OCCOC(C)(C)C)OC(=O)OC(Br)COC(=O)OCCCOC(C)C</smiles>

Fig. 1. The designed target structures. 
selected as $n=12,22,112$, so as to cover a broad range of sizes. The lipophilic chain, R2, is palmitic acid, while R3 is a dicarboxylic acid component. Further, a single carbon atom, with or without substituent, links the carbonate and the ester functional groups. In this paper we present the results of our efforts to develop synthetic methods for these compounds. Also described are the surfactant properties of the mPEG carbonate ester derivatives. In the final section, this paper examines the biodegradability of these new amphiphilic molecules. It reports the rate of degradation of the double esters under enzymatic conditions. The results are compared with the degradation rate of the corresponding $\mathrm{mPEG}$ esters.

\section{Results and discussion}

Synthesis. Although other structural arrangements are possible, concern over the tolerability of the degradation products and the synthetic convenience weighed heavily in favour of the chosen target structures. The approaches towards the desired molecules are outlined in the retrosynthetic sketches shown in Fig. 2. These are: path (a) alkylative esterification of carboxylic acid 4 using the alkyl halide 3 and path (b) the acylation of monomethoxyPEG using the reagent 5 .

$\boldsymbol{A}$-B-Type. First we attempted the synthesis of the A-Btype substances as shown in Scheme 1. Here, the halide required in the alkylation process was obtained by treating $\mathrm{mPEG}$ alcohol with chloroalkyl chloroformate in the presence of pyridine. $^{7-9}$ The results are summarised in Table 1 and as can be seen, mPEG of selected molecular weights reacted to afford the corresponding carbonates 8. Analytical high-performance chromatography (HPLC $)^{10}$ served as a useful tool in monitoring the formation and purity of the products. Purification of products was easily accomplished by precipitation from ether solution of crude product by addition of pentane. ${ }^{11}$ The yields of product were almost identical in all cases, but the time for completion of reaction varied according to the molecular weight of the PEG employed. The moderate yields obtained in these reactions were probably due to increased solubility of the derivatives 8 in

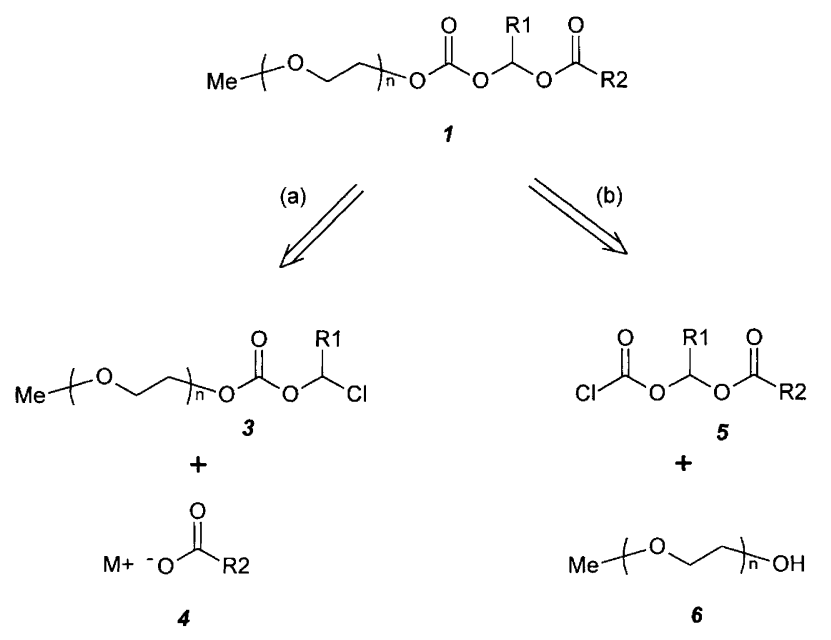

Fig. 2. Retroanalysis of target.

Table 1. Acylation of mPEG using chloroalkyl chloroformates.

\begin{tabular}{lrlcl}
\hline Compound & $n$ & $\mathrm{R}^{2}$ & $\begin{array}{l}\text { Reaction } \\
\text { time/h }\end{array}$ & Yield (\%) \\
\hline $\mathbf{8 a}$ & 12 & $\mathrm{H}$ & 3 & 59 \\
$\mathbf{8 b}$ & 22 & $\mathrm{H}$ & 3 & 63 \\
$\mathbf{8 c}$ & 112 & $\mathrm{H}$ & 72 & 61 \\
$\mathbf{8 d}$ & 12 & $\mathrm{CH}_{3}$ & 3 & 67 \\
$\mathbf{8 e}$ & 22 & $\mathrm{CH}_{3}$ & 3 & 68 \\
$\mathbf{8 f}$ & 112 & $\mathrm{CH}_{3}$ & 72 & 73 \\
\hline
\end{tabular}

the precipitation system and loss of material during the decantations. In addition, we observed that this acylation reaction of $\mathrm{mPEG}$ sizes was sensitive to the type of solvent employed. Thus, while THF was suitable solvent for acylation of mPEG of $n=12$ and 22, no reaction took place when MPEG of $n=112$ was employed. This large sized $\mathrm{mPEG}$ was eventually acylated in acetonitrile under standard conditions.

With the PEG chloroalkyl carbonate secured, $O$ alkylation of palmitic acid ${ }^{12}$ was attempted. Several methods have been reported in the literature for efficient alkylative esterification carboxylic acids where a variety
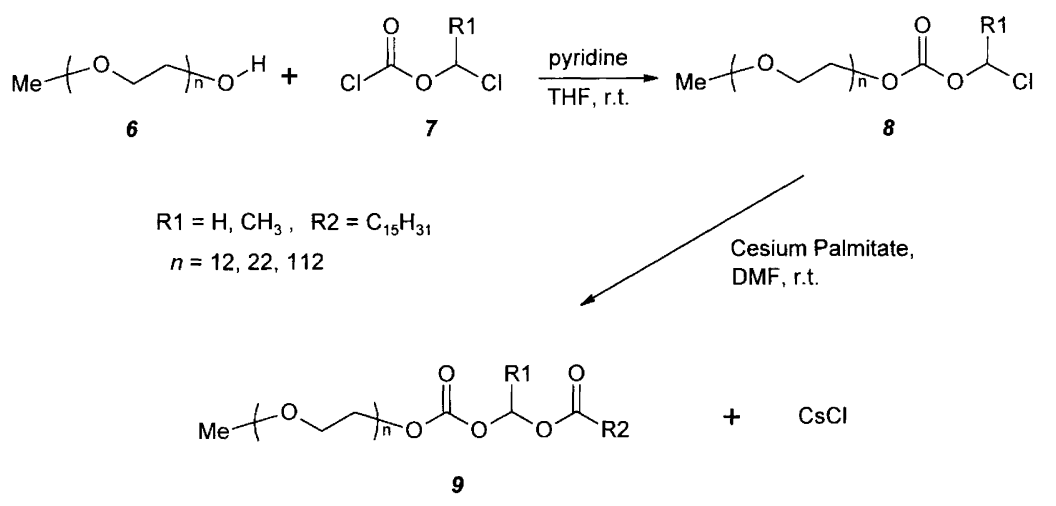

Scheme 1. 
of their metal and non-metal salts reacted with simple alkyl halides or tosylates. ${ }^{13}$ When gem-dihalides are employed structurally related diesters (acylals) have been obtained. ${ }^{14}$ By contrast, our electrophilic $\alpha$-chloroalkyl carbonates $\mathbf{8}$ are ambident in nature and carboxylate nucleophiles can attack at both the $\alpha$-chlorocarbon and the carbonyl carbons, with the later leading to undesired products. Furthermore, heterolytic cleavage of the carbon-halogen bond in $\mathbf{8}$ is expected to result in high reactivity in nucleophilic substitution by $\mathrm{S}_{\mathrm{N}} 1$ and $\mathrm{S}_{\mathrm{N}} 2$ reactions. ${ }^{15}$ However, we discovered that conventional metal and non-metal cations ${ }^{16}$ such as $\mathrm{Li}^{+}, \mathrm{Na}^{+}, \mathrm{K}^{+}$, $\mathrm{Ag}^{+}, \mathrm{DBUH}^{+}, \mathrm{Et}_{3} \mathrm{NH}^{+}$as counter-ion on the palmitate failed to react and resulted in either the recovery of starting material or extensive decomposition. However, on the basis of earlier reports of success with cesium ${ }^{17}$ as counter-ion in alkylation reactions, cesium palmitate was prepared and treated with the halide 8 in DMF. A highly chemoselective reaction took place and products were obtained in good yield. The results from the esterification reactions are listed in Table 2 and deserve some comments. Both mPEG chloromethyl carbonates and the 1-chloroethyl homologues reacted chemoselectively to afford the carbonate esters 9 in good to excellent yields. However, in contrast to the smooth reaction with chloromethyl carbonates, the alkylation with 1-chloroethyl carbonates gave a by-product which was observed as a peak on the HPLC chromatogram. From one reaction mixture this compound was isolated and spectroscopic data showed it to be mPEG alcohol. This was quite unexpected, since NMR analysis ruled out the presence of free mPEG alcohol as impurity in the starting halide. Because of the presence of $\mathrm{MPEG}$ alcohol in the reaction mixture, preparative HPLC was required in order to obtain the double esters $9 \mathbf{d}-\mathbf{f}$ in highly pure form. The appearance of $\mathrm{mPEG}$ alcohol in the reaction mixture was surprising, and we wanted to determine its origin and at the same time determine the optimal

Table 2. Alkylation reaction between cesium palmitate and mPEG chloroalkyl carbonate derivatives 8.

\begin{tabular}{lrlll}
\hline Compound & $n$ & $R^{2}$ & $\begin{array}{l}\text { Reaction } \\
\text { time/h }\end{array}$ & Yield (\%) \\
\hline 9a & 12 & $\mathrm{H}$ & 72 & 90 \\
9b & 22 & $\mathrm{H}$ & 72 & 63 \\
9c & 112 & $\mathrm{H}$ & 48 & 61 \\
9d & 12 & $\mathrm{CH}_{3}$ & 72 & 57 \\
9e & 22 & $\mathrm{CH}_{3}$ & 72 & 40 \\
9f & 112 & $\mathrm{CH}_{3}$ & 72 & 40 \\
\hline
\end{tabular}

conditions in terms of the effects of variables such as temperature and solvents in this alkylation process. Thus, the following NMR test-tube experiments were designed: treatment of cesium palmitate with $\mathrm{mPEG}(n=12) 1$ chloroethyl carbonate $8 \mathbf{e}$ in deuteriated $\left({ }^{2} \mathrm{H}_{7}\right) \mathrm{DMF}$, $\left({ }^{2} \mathrm{H}_{4}\right)$ methanol and $\left({ }^{2} \mathrm{H}_{3}\right)$ acetonitrile. Spectral recordings were taken at intervals and analysed to monitor the disappearance of resonances from reactants and appearance of new ones from products. Briefly, the results of these explorations showed that: (1) the formation of product in DMF at $70^{\circ} \mathrm{C}$ was completed within $3 \mathrm{~h}$. Formation of product was accompanied by simultaneous formation of mPEG alcohol and acetaldehyde $(\delta$ 9.71-9.74 ppm (quartet) and $\delta 2.13-2.14 \mathrm{ppm}$ (doublet), $J=2.80 \mathrm{~Hz}$. This is shown in the ${ }^{1} \mathrm{H}$ NMR spectrum in Fig. 3. (2) No reaction at all took place in acetonitrile as the reactants remained unchanged even at $50^{\circ} \mathrm{C}$ for $20 \mathrm{~h}$. (3) In methanol at $50^{\circ} \mathrm{C}$ for $20 \mathrm{~h}$, reaction took quite an undesirable path and decomposition fragments traceable to the PEG alkylcarbonate were identified. On the basis of these findings the mechanism depicted in Scheme 4 in which DMF ${ }^{18}$ plays the dual role of solvent and reactant is proposed. Thus, it is assumed that the nucleophilic ${ }^{19}$ reaction follows a simultaneous $S_{N} 1$ and $\mathrm{S}_{\mathrm{N}} 2$ path. In this seldom but known mechanism, ${ }^{20}$ the molecules of mPEG 1-chloroethyl carbonate that react by the $\mathrm{S}_{\mathrm{N}} 2$ mechanism proceed through the accepted pentacoordinated intermediate $\mathbf{1 8}$ of the transition state to the expected product. On the other hand, for molecules that react by the $\mathrm{S}_{\mathrm{N}} 1$ mechanism, the oxonium cation 19, which is formed after the cleavage of the carbon-

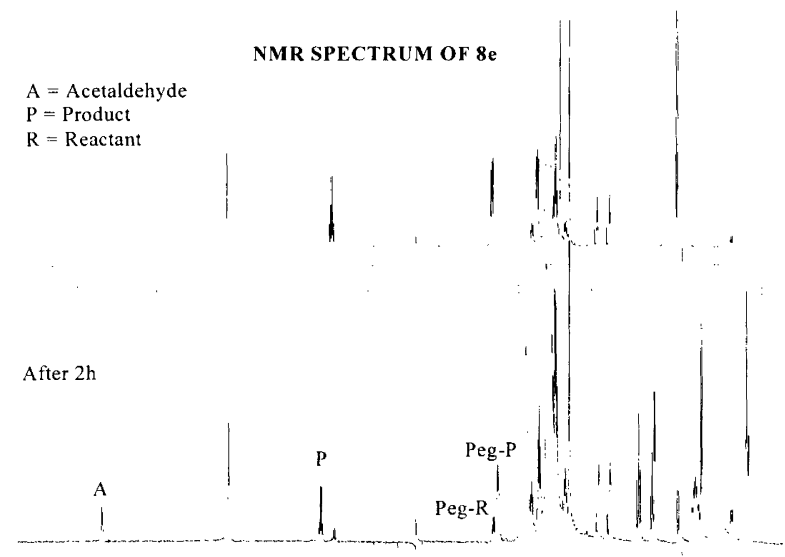

Fig. 3. The NMR spectrum during reaction between $8 \mathbf{e}$ and cesium palmitate.

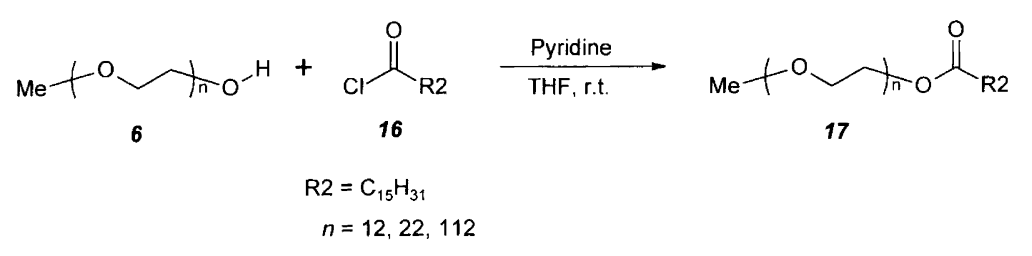

Scheme 2. 


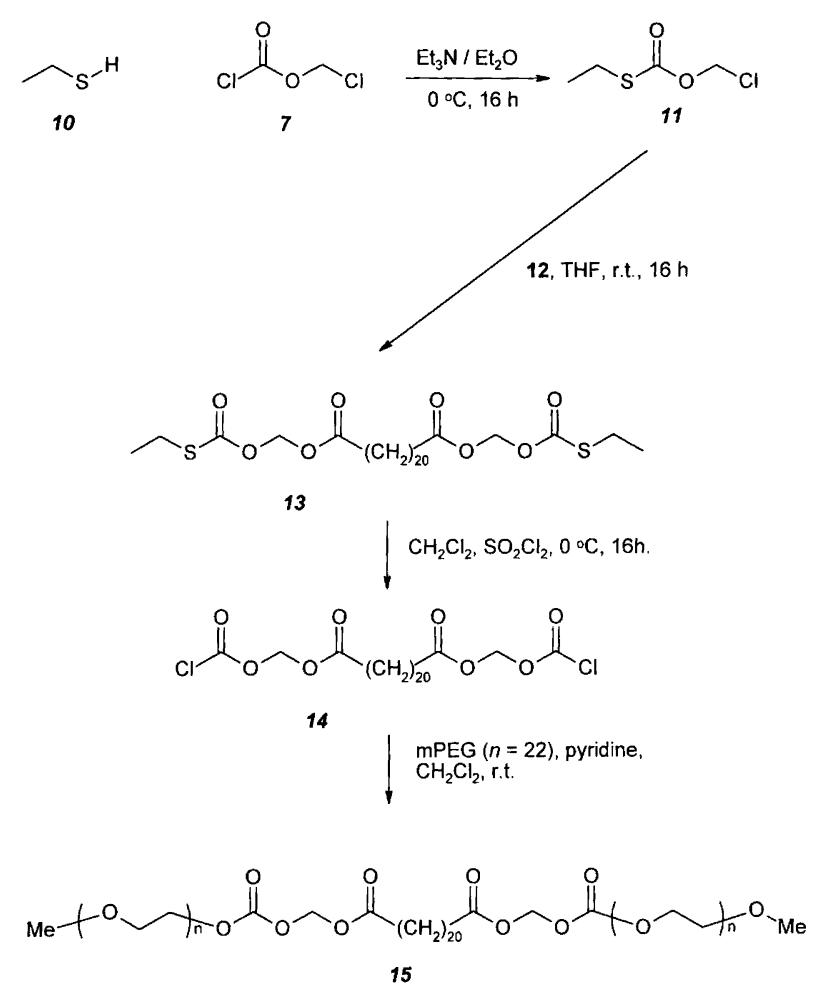

Scheme 3.

chloride bond, is intercepted by the oxygen of dimethylformamide, whose nucleophilicity is enhanced by association with cesium cation. ${ }^{21}$ Subsequent expulsion of carbon dioxide from the resulting arrangement 20 provides the driving force for the formation of $\mathrm{mPEG}$ alcohol (21) and acetaldehyde (23).

The superior reactivity of cesium over the other cations in the alkylation of the palmitate may be attributed to complexation by the oxygens of in the MPEG allowing it to act as template. ${ }^{22}$ It has been suggested that other factors such as low charge/surface area ratio due to the large ionic diameter of cesium ( $3.3 \AA$ ) may be of significance $^{23}$ in enhancing this type of reaction. Compounds $17 \mathbf{a}-\mathbf{c}$ in Table 3 are esters obtained by treating palmitoyl chloride $^{24}$ with $\mathrm{mPEG}$ alcohol and were used for comparative biodegradability studies.

$\boldsymbol{A}-\boldsymbol{B}-\boldsymbol{A}-$ Type. Only one example of the A-B-A structural geometry was considered necessary for our present purpose of biodegradability studies. Docosanedioic acid was chosen for this purpose primarily because its size (22 carbons), sandwiched between two mPEG $(n=22)$ chain lengths, was sufficient to give a reasonable hydrophilic/ lipophilic balance (HLB). However, in sharp contrast to the results obtained from our established alkylation

Table 3. Esters from MPEG and palmitoyl chloride.

\begin{tabular}{llll}
\hline Compound & $n$ & $\begin{array}{l}\text { Reaction } \\
\text { time/h }\end{array}$ & Yield (\%) \\
\hline 17a & 12 & 72 & 60 \\
17b & 22 & 24 & 61 \\
17c & 112 & 24 & 84 \\
\hline
\end{tabular}

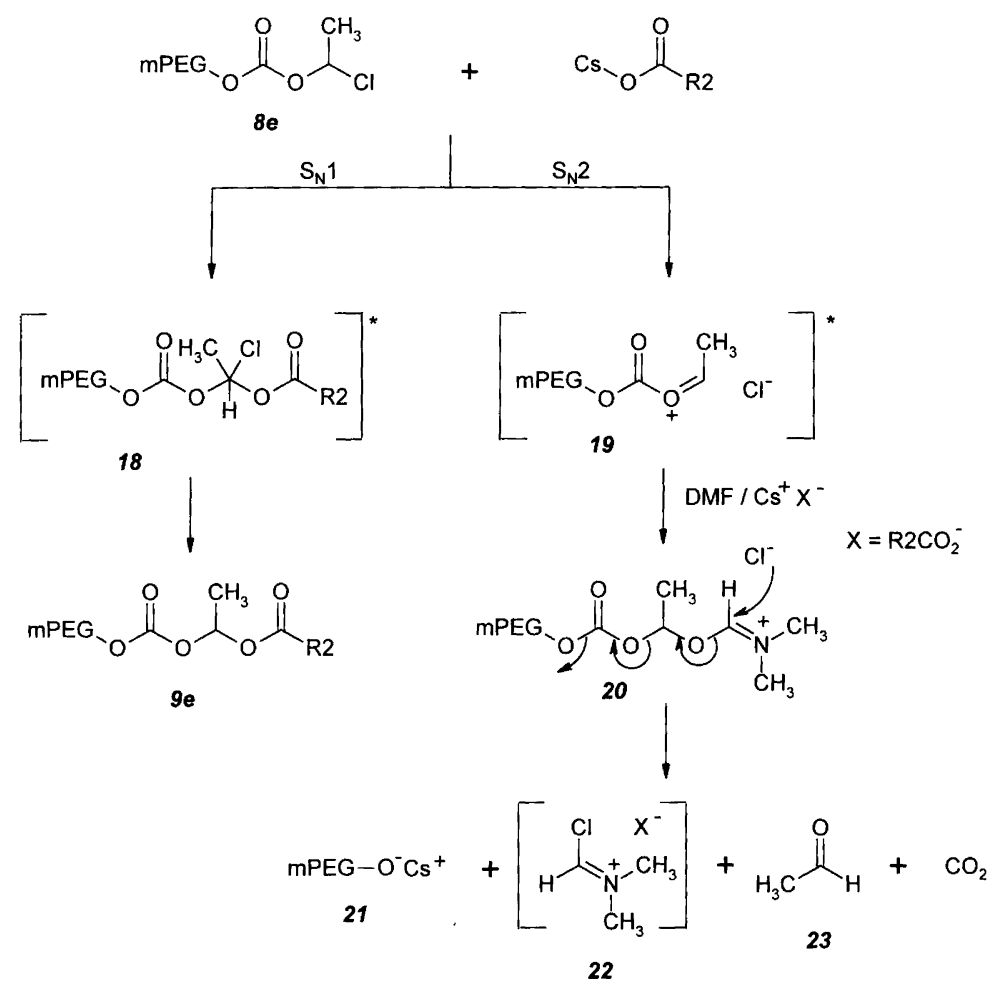

Scheme 4. 
procedure, the cesium salt of docosanedioic $\operatorname{acid}^{25,26}$ failed to react with our mPEG alkyl chloride 8 . The target compound was eventually obtained as outlined in Scheme 3 , which is in accordance with path (b) in the retro-analysis in Fig. 2. The key intermediate $\mathbf{1 4}$ required in the final acylation step was obtained by sulfuryl chloride chlorination ${ }^{27}$ of 13 , which in turn is the alkylation product of reaction between the bis(tetrabutylammonium) salt of docosanedioic acid 12 and the chloromethyl thiocarbonate 11. Treatment of $\mathrm{mPEG}$ alcohol $(n=22)$ with the diacid chloride 14 in a dichloromethane-pyridine mixture afforded the double carbonate ester $\mathbf{1 5}$ in good yield.

\section{Characterisation}

NMR analysis. NMR was well suited in establishing the structural integrity of the carbonate esters. All the mPEG carbonate esters and ordinary esters presented well defined NMR spectra with characteristics which corresponded well to the composition of the products. For the $\mathbf{A}-\mathbf{B}$ carbonate esters, proton NMR was efficient in determining the $\mathrm{mPEG}$ palmitic acid ratios from the integration of resonances due to MPEG methylene at $4.28 \mathrm{ppm}\left(-\mathrm{OCH}_{2}-\mathrm{CH}_{2}-\mathrm{OCO}_{2}-\right.$ multiplet $)$, carbonate ester linker at $5.75 \mathrm{ppm}\left(-\mathrm{O}_{2} \mathrm{CO}-\mathrm{CH}_{2}-\mathrm{OCOR}\right.$, singlet $)$ and palmitic acid at $2.36 \mathrm{ppm}\left(-\mathrm{OCOCH}_{2}\right.$, triplet). When the linker is 1-ethylene, the resonance due to methine appears at $6.53 \mathrm{ppm}$ as a quartet, $\left(-\mathrm{O}_{2} \mathrm{CO}-\mathrm{CHCH}_{3}-\mathrm{OCOR}\right)$ and the methyl at $1.53 \mathrm{ppm}$ ( $-\mathrm{O}_{2} \mathrm{CO}-\mathrm{CHCH}_{3}-\mathrm{OCOR}$, doublet).

The important carbon atom assignments in the ${ }^{13} \mathrm{C}$ spectra are the resonances at 175.1 and $154.0 \mathrm{ppm}$, which correspond to the ester and carbonate carbonyl carbons, respectively. For the 1-ethylene analogue, these resonances are slightly shifted to 171.7 and $153.1 \mathrm{ppm}$. Definitive proof of the authencity of the proposed structures of the carbonate esters was obtained from hetero multiple quantum correlation experiments (HMQC), where long-range couplings were observed between the bridge proton and the carbonyl carbons from the fatty acid and the carbonate components.

Surface activity and critical micellar concentration $(C M C)$. A fundamental property of surfactants is the ability to reduce the normally high surface tension of water. The surface activity of these new mPEG carbonate esters was established by measuring the surface tensions of their aqueous solutions. The data obtained by the Wilhemy plate method ${ }^{28}$ on K1O ST (Kruss, Germany) tensiometer are reported in Fig. 4. As can be seen, low concentrations of the carbonate esters are sufficient to lower the surface tension of water from 73 to $35 \mathrm{mN} \mathrm{m}^{-1}$. It is also clear from the figure that increasing the size of mPEG moiety leads to a corresponding decrease in the surface tension reducing ability of the surfactant. Plots of the surface tension reduction versus the logarithm of

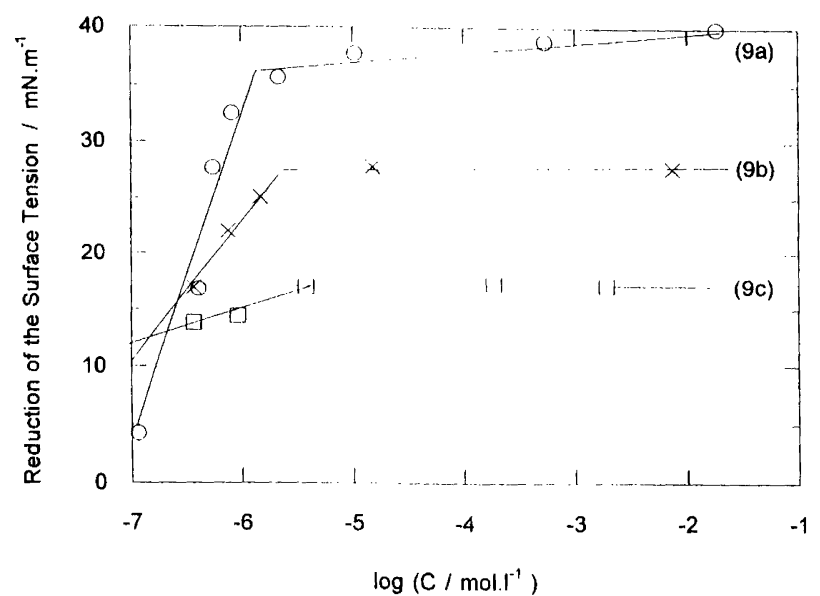

Fig. 4. The reduction of surface tensions for $\mathrm{MPEG}$ carbonate ester surfactants at various concentrations of aqueous solutions. The breaks correspond to the $\mathrm{CMC}$ values.

concentration gave sharp breaks corresponding to the CMC values ${ }^{29}$ listed in Table 4.

Hydrolysis studies. Representative mPEG surfactants were selected for enzymatic hydrolysis studies. The experiments were performed in a $\mathrm{pH}$-stat and carried out at ambient temperature in water containing DMF $(8 \%)$ and the enzyme, pig liver esterase (PLE). Reactions were run at $\mathrm{pH} 8.2$, with and without enzyme. Constant $\mathrm{pH}$ during hydrolysis was assured by simultaneous addition of $5 \mathrm{mM} \mathrm{NaOH}$ (titrant) from the autoburette. The rates, $r$ mmol $\mathrm{min}^{-1}$ for the liberation of acidic metabolites (carbon dioxide and palmitic acid) from the hydrolysis by PLE were calculated from the amount of base consumed in the reaction, and verification of metabolites was supported by proving the presence of mPEG by HPLC and MALDI-MS. Some of the compounds studied and their associated degradation data are listed in Table 5. As can be seen from the data, all the compounds underwent faster hydrolysis in the presence of pig liver

Table 4. Determined CMC for MPEG carbonate ester surfactants.

\begin{tabular}{ll}
\hline Compound & $\mathrm{CMC} / \mathrm{mol} \mathrm{dm}^{-3}$ \\
\hline $9 \mathrm{a}(n=12)$ & $1.2 \times 10^{-6}$ \\
$9 \mathrm{~b}(n=22)$ & $2.3 \times 10^{-6}$ \\
$9 \mathrm{c}(n=112)$ & $4.4 \times 10^{-6}$ \\
\hline
\end{tabular}

Table 5. Rate values for enzymatic hydrolysis of some carbonate ester surfactants as determined by the $\mathrm{pH}$-stat.

\begin{tabular}{lll}
\hline & \multicolumn{2}{l}{ Rate of hydrolysis $\mathrm{mmol} \mathrm{min}^{-1}$ at $\mathrm{pH} 8.2$} \\
\cline { 2 - 3 } Compound & PLE & Without PLE \\
\hline $9 a$ & 1.30 & 0.04 \\
$9 \mathrm{e}$ & 0.70 & - \\
$\mathbf{1 7}$ & 0.30 & 0.06 \\
$\mathbf{1 5}$ & 0.47 & - \\
\hline
\end{tabular}


esterase than without esterase irrespective of whether they contained a single ester or a carbonate ester. However, while the single ester 17a was hydrolysed 5 times faster than without esterase, hydrolysis was 32.5 times faster with the methylene-bridged carbonate ester 9b under identical conditions. For the ethylene-bridged carbonate ester hydrolysis was ca. 20 times faster and 12 times faster in the case of the double carbonate ester variant, 15.

Performing the hydrolysis at $\mathrm{pH} 8.2$ is beneficial because it is above the $\mathrm{p} K_{\mathrm{a}}$ values of both palmitic acid $\left(\mathrm{p} K_{\mathrm{a}} 5.0\right)$ and $\mathrm{HCO}_{3}{ }^{-}\left(\mathrm{p} K_{\mathrm{a}} 6.1\right)$ and thus eliminates the buffering capacity of these species. It also allows the sum of liberated metabolic carbon dioxide and palmitic acid to be determined by a simple neutralisation titration reaction.

In order to generate comparative data for rates of hydrolysis, the ideal condition is to use $V_{\max }$ values from Lineweaver-Burk plots. ${ }^{30}$ With these surfactants exhibiting CMC values of $10^{-6} \mathrm{M}$, construction of Lineweaver-Burk plots would require substrate concentrations too low to be detected with proper accuracy. Therefore, a fixed amount of enzyme $(100 \mu 1)$ and a nearly constant weight of substrate $(28-30 \mathrm{mg})$ were chosen, and the reaction was recorded from start to end with the $\mathrm{pH}$-stat. Thus, the measured rate is an 'overall reaction rate' and not an expression of $V_{\max }$ for the enzyme-substrate couple. Despite the limiting factors mentioned above, the method was found appropriate to determine the reaction velocities when performed together with HPLC analysis.

In summarising, chloroformates have been found to acylate efficiently mPEG alcohols of various sizes in the presence of pyridine to yield the corresponding chloroalkyl carbonates. These PEG derivatives are useful alkylating agents in the esterification of palmitic acid provided cesium is the counter-ion of the carboxylate. Generally, the alkylation is thought to proceed by an $\mathrm{S}_{\mathrm{N}} 2$ mechanism; however, a competitive $\mathrm{S}_{\mathrm{N}} 1$ mechanism becomes dominant in the reaction of $\mathrm{mPEG}-1$-chloroethyl carbonate with cesium palmitate and resulted in the reversal of this intermediate to the starting materials. By first alkylating the ditetrabutylammonium salt of docosanedioic acid using chloromethyl carbonothioate and conversion to the diacyl chloride, mPEG alcohol was acylated to afford $\mathbf{A}-\mathbf{B}-\mathbf{A}$ type molecular structure. These $\mathrm{mPEG}$ derivatives containing unique carbonate ester functions have been studied to establish their properties as surfactants and rates of hydrolyses. They were found to be hydrolysed considerably faster than the corresponding single ester in the presence of esterase. The proven properties should therefore make these surfactants attractive in the development of pharmaceutical applications as solubilisers, wetting agents and drug delivery matrices.

\section{Experimental}

General methods. HPLC analyses were performed using a $\mathrm{C} 8$ reversed-phase column (Beckman-ultrasphere) under gradient conditions with a 75:25 mixture $(\mathrm{v} / \mathrm{v})$ of tetrahydrofuran-water and $0.1 \%$ trifluoroacetic acid. For preparative HPLC, $20 \mathrm{~mm} \times 27.5 \mathrm{~cm}$, RP-8 Lichroprep, $15-25 \mu \mathrm{m}$ in a two-step gradient, (A) $48 \%$ acetonitrile in water and (B) 93\% acetonitrile in water was used. The peak elusions were monitored with UV $(280 \mathrm{~nm})$ and RI coupled series. All NMR experiments were recorded on a Varian VXR-300S spectrometer using a broad band probe with $5 \mathrm{~mm}$ tube. Sample dissolved in $\mathrm{CDCl}_{3}$ unless otherwise stated. Chemical shifts are reported relative to $\mathrm{Me}_{4} \mathrm{Si}$ and $\mathrm{CDCl}_{3}$. Liquid chromatography was performed using silica gel (Merck 230-400 mesh). Thinlayer chromatography (TLC) was performed on kieselgel $60 \mathrm{~F}_{254}$ precoated plates $(0.25 \mathrm{~mm})$, and spots were visualised with molybdophosphoric acid in ethanol after heating. mPEG was dried in a vacuum with $\mathrm{P}_{2} \mathrm{O}_{5}$ for $24 \mathrm{~h}$ or in activated $4-\AA$ molecular sieves in appropriate solvents.

Materials. Ethyl acetate, petroleum ether and $\mathrm{CH}_{2} \mathrm{Cl}_{2}$ were used as received. DMF and THF were dried over $3 \AA$ molecular sieves. Polyethylene glycols with one methoxy and one hydroxyl end group (mPEG) were purchased from shearwater Polymers, Inc.

\section{General procedure}

Carbonic acid chloromethyl ester mPEG ester $(\mathbf{8 a}-\mathbf{c})$. To a stirred solution of dried monomethoxy polyethylene glycol (mPEG, $n=12)(10.27 \mathrm{~g}, 10 \mathrm{mmol})$ in anhydrous tetrahydrofuran, THF $(100 \mathrm{ml})$ and pyridine $(3.40 \mathrm{ml}$, $40 \mathrm{mmol}$ ) was added chloromethyl chloroformate ( $3.60 \mathrm{ml}, 40 \mathrm{mmol})$ at ambient temperature. Monitoring by HPLC showed that after $3 \mathrm{~h} 97 \%$ of product has been formed. The precipitated pyridinium hydrochloride salt was removed by filtration and the solvent removed by evaporation. The viscous oily residue was dissolved in ether $(150 \mathrm{ml})$ or chloroform for mPEG $(n=112)$ and the pegylated product was precipitated by addition of pentane $(200 \mathrm{ml})$. Decantation of the solvents and drying of the residue under vacuum gave the pure product as a viscous oil, yield: $7.27 \mathrm{~g}(59 \%)$. ${ }^{1} \mathrm{H}$ NMR: $\delta 3.37-4.38$ (m, mPEG), 5.73 (s, $2 \mathrm{H}$ ). ${ }^{13} \mathrm{C}$ NMR: $\delta$ 59.0, 68.1, 68.6, 70.5, 71.9, 72.2, 76.6, 153.3. IR (neat): 2873, 1767, 1450, $1349,1256,1110,788 \mathrm{~cm}^{-1}$.

Hexadecanoic acid mPEG-oxycarbonyloxymethyl ester (9a-c). A mixture of palmitic acid $(0.40 \mathrm{~g}, 1.55 \mathrm{mmol})$ and cesium carbonate $(0.65 \mathrm{~g}, 2.0 \mathrm{mmol})$ in dimethyl formamide, DMF ( $10 \mathrm{ml})$ was stirred at ambient temperature for $45 \mathrm{~min}$ before a solution of carbonic acid chloromethyl ester mPEG $(n=12)$ ester (8a) $(1.0 \mathrm{~g}$, $1.55 \mathrm{mmol}$ ) in DMF ( $3 \mathrm{ml}$ ) was added. The reaction was monitored by HPLC, and after $72 \mathrm{~h}$ ( $95 \%$ conversion) the mixture was filtered and DMF removed under reduced pressure. The residue was dissolved in chloroform $(30 \mathrm{ml})$ and extracted with saturated sodium bicarbonate solution $(1 \times 15 \mathrm{ml})$ and water $(1 \times 15 \mathrm{ml})$. Drying $\left(\mathrm{MgSO}_{4}\right)$, filtration and evaporation of the chlo- 
roform phase gave the product as a white wax, $1.20 \mathrm{~g}$ (90\%). ${ }^{1} \mathrm{H}$ NMR: $\delta$ 0.85-1.63 (m, $\left.29 \mathrm{H}\right), 1.60-1.63(\mathrm{~m}$, $2 \mathrm{H}), 3.37-4.34$ (m, mPEG), $5.75(\mathrm{~s}, 2 \mathrm{H}) .{ }^{13} \mathrm{C}$ NMR: $\delta$ $14.1,22.6,24.5,31.9,33.8,59.0,61.5,67.6,68.6,81.8$, $154.0,172.1$. IR (neat): 2886, 1765, 1468, 1344, 1280, $1149,1114,947,842 \mathrm{~cm}^{-1}$.

Carbonic acid 1-chloroethyl ester mPEG ester $(\mathbf{8 d}-\mathbf{f})$. To a stirred solution of dried mPEG $(n=22),(\mathbf{6 b})(10 \mathrm{~g}$, $10.00 \mathrm{mmol})$ in anhydrous, THF $(150 \mathrm{ml})$ and pyridine ( $1.60 \mathrm{ml}, 20.00 \mathrm{mmol}$ ) was added 1-chloroethyl chloroformate $(2.20 \mathrm{~g}, 20.00 \mathrm{mmol})$ at ambient temperature. After $3 \mathrm{~h}$ the precipitated pyridinium hydrochloride salt was removed by filtration and the solvent removed by evaporation. The viscous oily residue was dissolved in ether $(150 \mathrm{ml})$ or chloroform for mPEG5000 and the mPEG product was precipitated by addition of pentane $(200 \mathrm{ml})$. Decantation of the solvents and drying of the residue under vacuum gave the pure product as a viscous oil, $7.55 \mathrm{~g}(68 \%)$. ${ }^{1} \mathrm{H}$ NMR: $\delta 1.83(\mathrm{~d}), 3.54-4.36(\mathrm{~m}$, mPEG), 6.40-6.44 (q, 1 H). ${ }^{13} \mathrm{C}$ NMR: $\delta 25.1,59.0$, $67.8,68.6,70.5,70.6,71.9,84.6,152.8$. IR (neat): 2884 , $1764,1468,1345,1280,1147,1115,965,842 \mathrm{~cm}^{-1}$.

Hexadecanoic acid 1-mPEG oxycarbonyloxyethyl ester (9d-f). Cesium palmitate was obtained by stirring a mixture of palmitic acid $(0.50 \mathrm{~g}, 1.95 \mathrm{mmol})$ and cesium carbonate $(1.0 \mathrm{~g}, 3 \mathrm{mmol})$ in water $(20 \mathrm{ml})$ for $30 \mathrm{~min}$. After evaporation of water, the residue was dried under high vacuum over $\mathrm{P}_{2} \mathrm{O}_{5} /$ blue gel for $24 \mathrm{~h}$. To a suspension of the cesium salt in dimethyl formamide, DMF $(10 \mathrm{ml})$ was added a solution of carbonic acid 1-chloroethyl ester mPEG $(n=22)(8 \mathrm{e})(2.16 \mathrm{~g}, 1.95 \mathrm{mmol})$ in DMF $(3 \mathrm{ml})$ and stirred at ambient temperature for $45 \mathrm{~min}$. The reaction was monitored by HPLC and after $72 \mathrm{~h}(65 \%$ conversion) the mixture was filtered and DMF removed under reduced pressure. The residue was then dissolved in chloroform $(30 \mathrm{ml})$ and extracted with saturated sodium bicarbonate $(1 \times 15 \mathrm{ml})$ and water $(1 \times 15 \mathrm{ml})$. Drying $\left(\mathrm{MgSO}_{4}\right)$, filtration and evaporation of the chloroform phase gave the crude product as a white wax, $2.53 \mathrm{~g}(98 \%)$. Pure product was obtained by preparative HPLC as a white wax, $1.03 \mathrm{~g}(40 \%) .{ }^{1} \mathrm{H}$ NMR: $\delta$ 0.75-2.52 (m, 29 H), 1.29 (d, $3 \mathrm{H}), 1.50(\mathrm{~d}, 3 \mathrm{H}, J=$ $6 \mathrm{~Hz}), 2.10(\mathrm{~m}, 2 \mathrm{H}), 3.07-4.34$ (m, mPEG), 6.62 (q, $1 \mathrm{H}, \mathrm{q}, J=6 \mathrm{~Hz}) .{ }^{13} \mathrm{C}$ NMR: $\delta 14.0,20.6,22.5,24.5$, $32.8,34.0,59.1,67.5,67.6,68.6,81.8,153.0,169.1$. IR (neat): $2887,1765,1468,1344,1280,1149,1114,965$, $947,842 \mathrm{~cm}^{-1}$.

mPEG palmitoyl ester $(\mathbf{1 7 a}-\mathbf{c})$. Monomethoxy polyethylene glycol (mPEG, $n=22)$ (6b) $(6.0 \mathrm{~g}, 6.0 \mathrm{mmol})$ pyridine $(0.72 \mathrm{ml}, 9.0 \mathrm{mmol})$ and palmitoyl chloride (16) $(2.5 \mathrm{~g}, 9.0 \mathrm{mmol})$ were dissolved in THF $(110 \mathrm{ml})$, and stirred at ambient temperature for $24 \mathrm{~h}$. The precipitated pyridinium hydrochloride salt was filtered off and the solvent removed in vacuo. The residue was redissolved in chloroform $(100 \mathrm{ml})$ and extracted once each with saturated $\mathrm{NaHCO}_{3}(60 \mathrm{ml})$ and water $(60 \mathrm{ml})$ dried $\left(\mathrm{MgSO}_{4}\right)$ and evaporated. This residue was dissolve in ether $(50 \mathrm{ml})$ or chloroform for mPEG $(n=112)$ and the derivatised $\mathrm{mPEG}$ product precipitated by addition of pentane $(100 \mathrm{ml})$. Decantation of the solvents and drying of the residue under vacuum gave the pure product $(\mathbf{1 7 b})$ as a white compound, $4.50 \mathrm{~g}(60 \%) .{ }^{1} \mathrm{H}$ NMR: $\delta$ $0.85-0.91(\mathrm{t}, 3 \mathrm{H}), 1.25-1.27(\mathrm{~m}, 26 \mathrm{H}), 1.51(\mathrm{t}, 2 \mathrm{H})$, 2.29-2.34 (t, $2 \mathrm{H}), 3.37-3.39(\mathrm{~m}, \mathrm{mPEG}), 4.20-4.23(\mathrm{t}$, $2 \mathrm{H}) .{ }^{13} \mathrm{C}$ NMR: $\delta 14.1,22.5,24.9,29.1,29.3,31.9,34.2$, 59.0, 63.3, 69.2, 70.5, 71.9, 173.8. IR (neat): 2873,1767 , $1450,1349,1256,1110,788 \mathrm{~cm}^{-1}$.

Thiocarbonic acid O-chloromethyl ester S-ethyl ester (11). A solution of $\mathrm{EtSH}(18.50 \mathrm{ml}, 250 \mathrm{mmol})$ and $\mathrm{Et}_{3} \mathrm{~N}$ $(34.65 \mathrm{ml}, 250 \mathrm{mmol})$ in ether $(100 \mathrm{ml})$ was added during $2 \mathrm{~h}$ to a stirred solution of chloromethyl chloroformate $(22 \mathrm{ml}, 250 \mathrm{mmol})$ in ether $(450 \mathrm{ml})$ at $0^{\circ} \mathrm{C}$. Stirring was continued for $30 \mathrm{~min}$ at $0{ }^{\circ} \mathrm{C}$ and then for $16 \mathrm{~h}$ at ambient temperature. Filtration, evaporation of solvent and distillation of the residue gave the pure product as a colourless liquid, $11.69 \mathrm{~g}(30 \%)$ : b.p. $50-54{ }^{\circ} \mathrm{C} / 15 \mathrm{mbar} .{ }^{1} \mathrm{H}$ NMR: $\delta 1.35(\mathrm{t}, 3 \mathrm{H}, J=7 \mathrm{~Hz}), 2.93(\mathrm{q}, 2 \mathrm{H}, J=7 \mathrm{~Hz}), 5.77$ (s, $2 \mathrm{H}) .{ }^{13} \mathrm{C}$ NMR: $\delta$ 14.70, 25.59, 34.44, 70.13, 72.52. 170.25 .

Docosanedioic acid bis(ethylsulfanyl) carbonyloxymethyl ester (13). To a stirred suspension of docosanedioic acid $(0.5 \mathrm{~g}, 1.35 \mathrm{mmol})$ in water $(5 \mathrm{ml})$ was added tetrabutylammonium hydroxide solution $(40 \%, 1.50 \mathrm{M}$, $1.80 \mathrm{ml}, 2.70 \mathrm{mmol}$ ) at ambient temperature. The resultant clear and colourless solution was stirred at ambient temperature for $10 \mathrm{~min}$ and was lyophilised to afford a viscous oil. This oil 12, dissolved freely in THF $(10 \mathrm{ml})$ and was added dropwise to a stirred solution of $\mathbf{1 1}$ $(0.40 \mathrm{~g}, 2.70 \mathrm{mmol})$ in THF $(5 \mathrm{ml})$. The reaction was monitored by TLC. After $24 \mathrm{~h}$ the mixture was filtered, the precipitate washed with THF $(3 \mathrm{ml})$ and the filtrate evaporated. The residue was triturated with ether $(30 \mathrm{ml})$ and filtered again to remove more precipitate. Evaporation of the ether gave almost pure product as a white solid, $0.76 \mathrm{~g},(93 \%) .{ }^{1} \mathrm{H}$ NMR: $\delta 1.25,1.62$ and $2.36(\mathrm{~m}, 40 \mathrm{H}), 1.40(\mathrm{t}, 3 \mathrm{H}), 2.90(\mathrm{q}, 2 \mathrm{H}), 5.80(\mathrm{~s}$, $2 \mathrm{H}) .{ }^{13} \mathrm{C}$ NMR: $\delta 14.7,24.5,25.4,28.9,29.2,29.4,29.6$, $29.7,33.9,80.1,170.7,172.2$. IR (neat): 2919, 2850, 1771, $1726,1473,1440,1320,1221,1159,1107,1086,1052$, $965,877 \mathrm{~cm}^{-1}$.

Docosanedioic acid bis(chlorocarbonyl)oxymethyl ester (14). A stirred solution of docosanedioic acid bis(ethylsulfanyl)carbonyloxymethyl ester (13) (320 mg, $0.53 \mathrm{mmol}$ ) in $\mathrm{CH}_{2} \mathrm{Cl}_{2}(5 \mathrm{ml})$ was cooled to $5^{\circ} \mathrm{C}$ (dry ice/methanol bath) and a solution of freshly distilled $\mathrm{SO}_{2} \mathrm{Cl}_{2}(0.14 \mathrm{~g}, 86 \mu \mathrm{l}, 1.06 \mathrm{mmol})$ in $\mathrm{CH}_{2} \mathrm{Cl}_{2}(2 \mathrm{ml})$ was added dropwise through a syringe. The clear and colourless solution was stirred at $0^{\circ} \mathrm{C}$ for $15 \mathrm{~min}$ followed by stirring at ambient temperature for $50 \mathrm{~min}$. Evaporation of the formed $\mathrm{EtSCl}$ at ambient temperature and $20 \mathrm{mbar}$ for $16 \mathrm{~h}$ gave 14 as a white substance, $262 \mathrm{mg}$, (89\%). ${ }^{1} \mathrm{H}$ NMR: $\delta$ 1.23, 1.62, $2.40(\mathrm{~m}, 40 \mathrm{H}), 5.82(\mathrm{~s}, 2 \mathrm{H})$. IR 
(neat): $2918,2850,1785,1474,1440,1130,1107,816$, $731 \mathrm{~cm}^{-1}$

Docosanedioic acid bis(mPEG1000 carbonyl) oxymethyl ester (15). Crude docosanedioic acid bis(chlorocarbonyl)oxymethyl ester (14) $(0.25 \mathrm{mg}, 0.45 \mathrm{mmol})$ was dissolved in $\mathrm{CH}_{2} \mathrm{Cl}_{2}(5 \mathrm{ml})$. A methylene chloride solution $(10 \mathrm{ml})$ of mPEG1000 $(0.91 \mathrm{~g}, 0.91 \mathrm{mmol})$ and pyridine $(72 \mu \mathrm{l}$, $0.91 \mathrm{mmol}$ ) was added and the mixture stirred at ambient temperature for 3 days. The mixture was extracted once each with $\mathrm{NaHCO}_{3}$ solution $(10 \mathrm{ml})$ and water $(10 \mathrm{ml})$. The organic phase was dried $\left(\mathrm{MgSO}_{4}\right)$, filtered and evaporated and the residue stirred for $2 \mathrm{~h}$ in ether $(15 \mathrm{ml})$. After decantation of the ether and drying in vacuo, the crude product was obtained as a white substance, $904 \mathrm{mg}$, and pure product was obtained after preparative HPLC, $265 \mathrm{mg},(24 \%) .{ }^{1} \mathrm{H}$ NMR: [1.26, s, 1.64, m, 1.74, s, 2.37 , $\mathrm{t}, 40 \mathrm{H}], 3.39-4.35(\mathrm{~m}, \mathrm{mPEG} 1000), 5.75(\mathrm{~s}, 4 \mathrm{H}) .{ }^{13} \mathrm{C}$ NMR: $\delta 24.5,29.0,29.2,29.4,29.6,29.7,33.9,59.0,67.6$, $68.6,70.7,71.9,81.8,154.0,172.1$. IR (neat): 2919, 2852, $1765,1468,1345,1280,1148,1114,1061,965,947$, $843 \mathrm{~cm}^{-1}$

Acknowledgement. Nycomed Imaging A/S is gratefully acknowledged for permission to publish this work. We are also grateful to Professor Leiv K. Sydnes for useful advice and encouragement. Silje S. Norbø and Willy Skjøld are thanked for performing the HPLC analysis.

\section{References}

1. Sagrado, F. G., Guzman, M., Molpeceres, M. R. and Aberturas, M. R. Pharm. Technol. Eur. (1994), May, 46 (part I); June, 38 (part II).

2. (a) Bianana-Limbele, W., Van Os, N. M., Rupert, L. A. M. and Zana, R. J. Colloid Interface Sci. 144 (1991) 458; (b) Craven, J. R., Hao, Z. and Booth, C. J. Chem. Soc., Faraday Trans. 87 (1991) 1183; (c) Harris, J. M. Rev. Macromol. Chem. Phys. C 25 (1985) 525.

3. Harris, J. M., Struck, E. C., Case, M. G., Paley, S., Van Alstine, J. M. and Brooks, D. E. J. Polym. Sci.; Polym. Ed. 22 (1984) 341.

4. (a) Shaffer, C. B. and Critfield, F. H. J. Am. Pharm. Ass. (1947) 152; (b) Richter, A. W. and Åkerblom, E. Int. Arch. Allergy Appl. Immunol. 70 (1983) 124; (c) Herold, D. A., Keil, K. and Bruns, D. E. Biochem. Pharmacol. 38 (1989) 73; (d) Sivikumaran, T., Jenkins, R. T. Walker, W. H. C. and Goodacre, R. L. Clin. Chem. 28 (1982) 2452.

5. Lawrence, M. J. Chem. Soc. Rev. (1994) 417.

6. Klaveness, J., Redford, K., Rongved, P., Solberg, J., Strande, P. and Wiggen, U. Int. Patent WO 93/17718 (1993).

7. Shanbhag, V. P. and Johansson, G. Biochem. Biophys. Res. Commun. 61 (1974) 1141.
8. Pillai, V. N. R., Mutter, M., Bayer, E and Gatfield, I. J. Org. Chem. 45 (1980) 5364.

9. (a) Kern, W., Iwabuchi, S., Sato, H. and Bohmer, V. Macromol. Chem. 180 (1979) 2539; (b) Zalipsky, S., Gillon, C. and Zilkha, A. Eur. Polym. J. 19 (1983) 1177.

10. (a) Rotman, A. M. J. Chromatogr. 253 (1982) 283; (b) Snyder, L. R. and Van Der Wal, S. J. J. Chromatogr. 255 (1983) 463; (c) Horvath, C., Nahum, A. and Melander, W. R. J. Chromatogr. 185 (1979) 129.

11. Case, M. G. and Harris J. M. J. Org. Chem. 48 (1983) 5390.

12. Stryer, L. Biochemistry, 3rd Edn., W. H. Freeman \& Co., NY 1988, p. 285

13. (a) Shaw, J. E. and Kunerth, D. C. J. Org. Chem. 39 (1974) 1968; (b) Holmberg, K. and Hansen, B. Tetrahedron Lett. 27 (1975) 2303; (c) Kavitake, B. P., Salunkhe, M. M. and Wadgaonakar, P. P. Synthetic Commun. 27 (1997) 1703.

14. Nycomed Patent WO $89 / 00988$.

15. (a) Olah, G. A. and Svoboda, J. J. Synthesis (1973) 53; (b) Senet, J.-P., Senney, G. and Wooden, G. P. Synthesis (1988) 407.

16. Ho, T.-L. Chem. Rev. (1975) 1

17. Van Keulen, B. J., Kellogg, R. M. and Pierpers, O. J. Chem Commun. (1979) 285.

18. Rajasekaharan Pillai, V. N. and Mutter, M. J. Org. Chem. 45 (1980) 5364

19. (a) Dijkstra, G., Kruizinga, W. H. and Kellogg, R. M. J. Org. Chem. 52 (1987) 4230; (b) Riondel, A., Caubere, P., Senet, J. P. and Lecolier, S. Tetrahedron 44 (1988) 1619.

20. (a) Sneen, R. A. Acc. Chem. Res. 6 (1973) 46; (b) Jencks, W. P. Chem. Soc. Rev. 10 (1981) 345; (c) Sneen, R. A., Felt, R. G. and Dickason, W. C. J. Am. Chem. Soc. 95 (1973) 638.

21. Arukwe, J. Acta Chem. Scand. 52 (1998) 819.

22. Reinhoudt, D. N., de Jong, F. and Tomassen, H. P. M. Tetrahedron Lett. 22 (1979) 2067

23. Cooper, S. R. Acc. Chem. Res. 21 (1988) 141.

24. (a) Shanbhag, V. P. and Johansson, G. Biochem. Biophys. Res. Commun. 61 (1974) 1141; (b) Pillai, V. N. R. Mutter, M., Bayer, E. and Gatfield, I. J. Org. Chem. 45 (1980) 5364; (c) Glass, J. D., Silver, L., Sondheimer, J., Pande, C. S. and Codere, J. Biopolymers 18 (1979) 383; (d) Okamoto, A., Hayashi, A., Uchiyama, K. and Mita, I. Eur. Polym. J. 19 (1983) 399.

25. (a) Charman, S. A., Charman, W. N., Rogge, M. C., Wilson, T. D., Dutko, F. J. and Pouton, C. W. Pharm. Res. 9 (1992) 87; (b) Yoshioka, T. and Florence, A. T. Int. Pharm. 108 (1994) 117.

26. Rashkov, I., Manolova, N., Li, S. M., Espartero, J. L. and Vert, M. Macromolecules 29 (1996) 50.

27. (a) Folkmann, M. and Lund, F. J. Synthesis (1990) 1159; (b) Benneche, T., Strande, P. and Wiggen, U. Acta Chem. Scand. 43 (1988) 74.

28. Dole, M. In Berl, W. G., Ed., Surface Tension Measurements, Physical Methods in Chemical Analysis, Vol. II (1951) p. 305.

29. (a) Bedpő, Z., Berecz, E. and Lakatos, I. Colloid Polym. Sci. 265 (1987) 715; (b) Mandal, A. B., Nair, B. U. and Ramaswamy, D. B. Electrochem. 4 (1988) 565.

30. Stryer, L. Biochemistry, 3rd Edn., W. H. Freeman \& Co., New York 1988, p. 187.

Received November 9, 1998 